\title{
SEISMIC VULNERABILITY OF FLAT PLATE COLUMN JOINT WITH OUT SLAB SHEAR REINFORCEMENT
}

\author{
Kavitha $\mathbf{S}^{1}$, Umadevi $\mathbf{R}^{2}$, Sugandha $\mathbf{N}^{3}$ \\ ${ }^{I}$ Reasearch scholar, Department of civil engineering, Acs college of engineering, karnataka, India \\ ${ }^{2}$ Assistant professor, Department of civil engineering, Acs college of engineering, karnataka, India \\ ${ }^{3}$ Assistant professor, Department of civil engineering, Acs college of engineering, karnataka, India
}

\begin{abstract}
During an earthquake, a brittle punching failure can arise in flat plate-column connections due to poor transfer capacity of shearing forces and unbalanced moments. To increase the shear capacity of the slab, various types of shear reinforcement can be used in the slab around the connection. The aim of the project is to study the response of slab column connections containing without slab shear reinforcement when subjected to combined gravity and cyclic lateral loading. At first a calibration model was developed to simulate the tested flat plate-column joint using finite element analysis program MASA. This model was used to predict the load displacement behaviour. The predicted behaviour was compared with the observed behaviour as reported by James Lee \& Ian Robertson (Ref.4). The comparison showed that the model predicts the load level excellently but significantly over estimates the stiffness of the joint compared to that observed by James Lee \& Ian Robertson. Since the present study is to compare the relative behaviour of slab-column joints provided without slab shear reinforcement, the error in the estimation of joint stiffness will not alter the comparative conclusions drawn. Thus, the developed model was validated for application to various types of column slab connection behaviour.
\end{abstract}

Keywords: Flat plate, slab column joint, punching shear, Drift and cyclic lateral loading

\section{INTRODUCTION}

Flat plate is one of the most common floor systems for large span commercial buildings. The advantages of a flat-Plate floor system are numerous. It provides architectural flexibility, more clear space, less building height, easier form work, and, consequently, shorter construction time. Low floor to floor heights reduce the total building height, thus reducing lateral loads, cost of building cladding, cost of vertical mechanical and electrical lines, and air conditioning/heating costs. For vertical loads, the structural performance and design of flat plates are well established. Under lateral loads, many aspects of the behavior of flat plates are uncertain. A serious problem that can arise in flat plates is brittle Punching Shear failure due to poor transfer capacity of shearing forces and unbalanced moments between slabs and columns. In seismic zones, a structure can be subjected to strong ground motions, and, for economical design, a structure is considered to undergo deformations in the inelastic range, therefore, in addition to strength requirement, slab-column connections must undergo these inelastic deformations without premature punching or shear failure. In other words slab column connections must have adequate ductility.

\section{METHODOLOGY}

$>$ Literature review on studies of slab column joints and Finite element analysis of reinforced concrete structures.

$>$ Developing of calibration model to simulate the tested flat plate-column connections.
$>$ Developing of finite element model to study the behavior of flat plate-column connections without slab shear reinforcement.

$>$ Come up with recommendations to improve the ductility of flat plate column joint under seismic loads.

\section{EXPERIMENTAL SETUP}

The finite element model of a flat plate-column joint an experimental load deformation behavior of a reinforced concrete flat plate-column joint without slab shear Reinforcement reported by James Lee \& Ian Robertson (Ref. 4) is considered for the study. The experimental details are discussed here. The test specimen represents an interior flat-slab and column connection in a prototype flat plate building, as shown in figures 1 and 2 . The specimen was tested in a steel reaction frame as shown in Figure 3. The slab reinforcement consisted of $\mathrm{Fe} 420$ grade reinforcement bars distributed as shown in figure 4 . The steel in the slab ran in both directions and three top and three bottom reinforcement bars passed through the column. The column was designed so as not to yield prior to slab flexural yielding. The predetermined cyclic lateral displacement routine was applied at the top of the column through a displacement-controlled actuator. The lateral displacement routine used in the test is as shown in figure 5. 


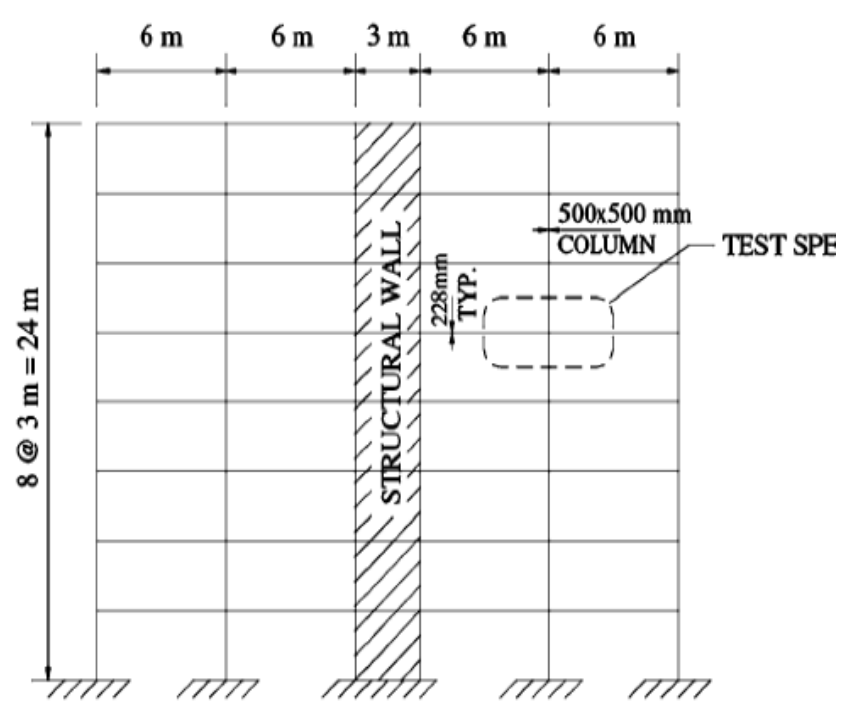

Fig. 1 Prototype structure

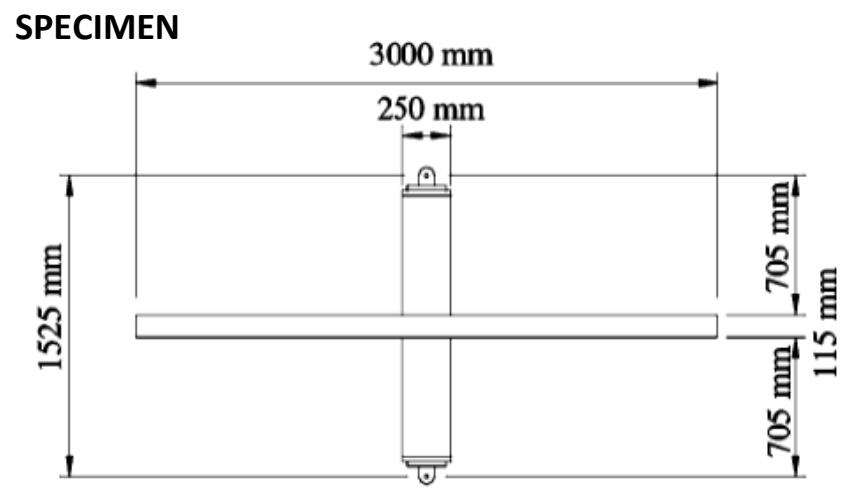

Fig. 2 Test specimen

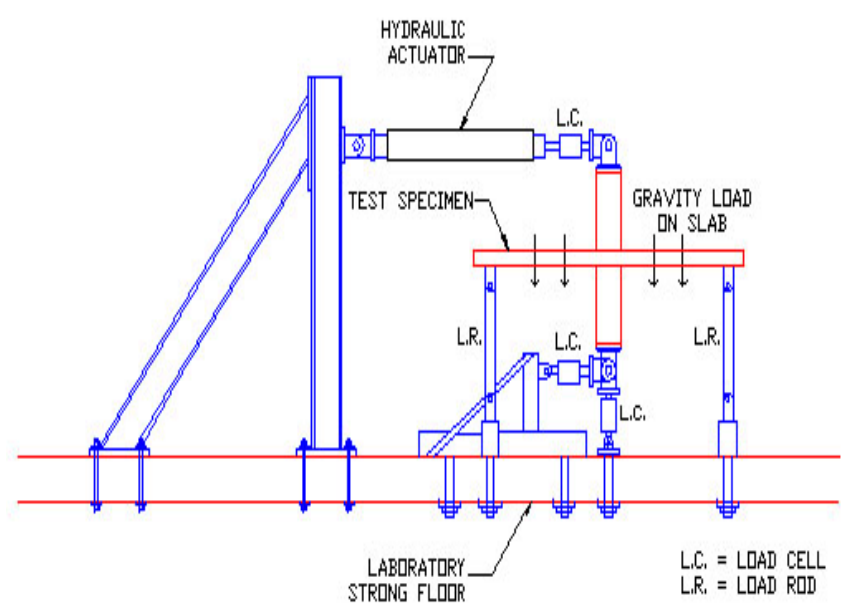

Fig. 3 Test setup

The test specimen supported a peak lateral load of $38.3 \mathrm{kN}$ at $+3.5 \%$ drift. It then experienced punching shear failure. The punching shear failure in Specimen resulted in a rupture at the surface of the slab (Fig.7). Failure was abrupt and occurred without warning. The figure 6 shows hysteretic curve for test specimen without slab shear reinforcement. Experimental results and The peak lateral load and drift at peak lateral load observed in the experiment are shown in the table 1

Table 1 Experimental results

\begin{tabular}{|l|l|l|l|l|}
\hline $\begin{array}{l}\text { Compressive } \\
\text { strength of } \\
\text { concrete } \\
\text { fc }^{\prime}\end{array}$ & $\begin{array}{l}\text { Peak } \\
\text { lateral } \\
\text { load }\end{array}$ & $\begin{array}{l}\text { Drift at } \\
\text { peak } \\
\text { load }\end{array}$ & $\begin{array}{l}\text { Unbalanced } \\
\text { moment } \\
\mathrm{Mu}\end{array}$ & $\begin{array}{l}\text { Shear } \\
\text { force } \\
\mathrm{Vu}\end{array}$ \\
\hline$(\mathrm{MPa})$ & $(\mathrm{kN})$ & $(\mathrm{mm})$ & $(\mathrm{kN}-\mathrm{m})$ & $(\mathrm{kN})$ \\
\hline 35.35 & 38.30 & 53.31 & 58.41 & 37.90 \\
\hline 35.35 & -33.60 & -45.66 & -51.24 & 39.90 \\
\hline
\end{tabular}

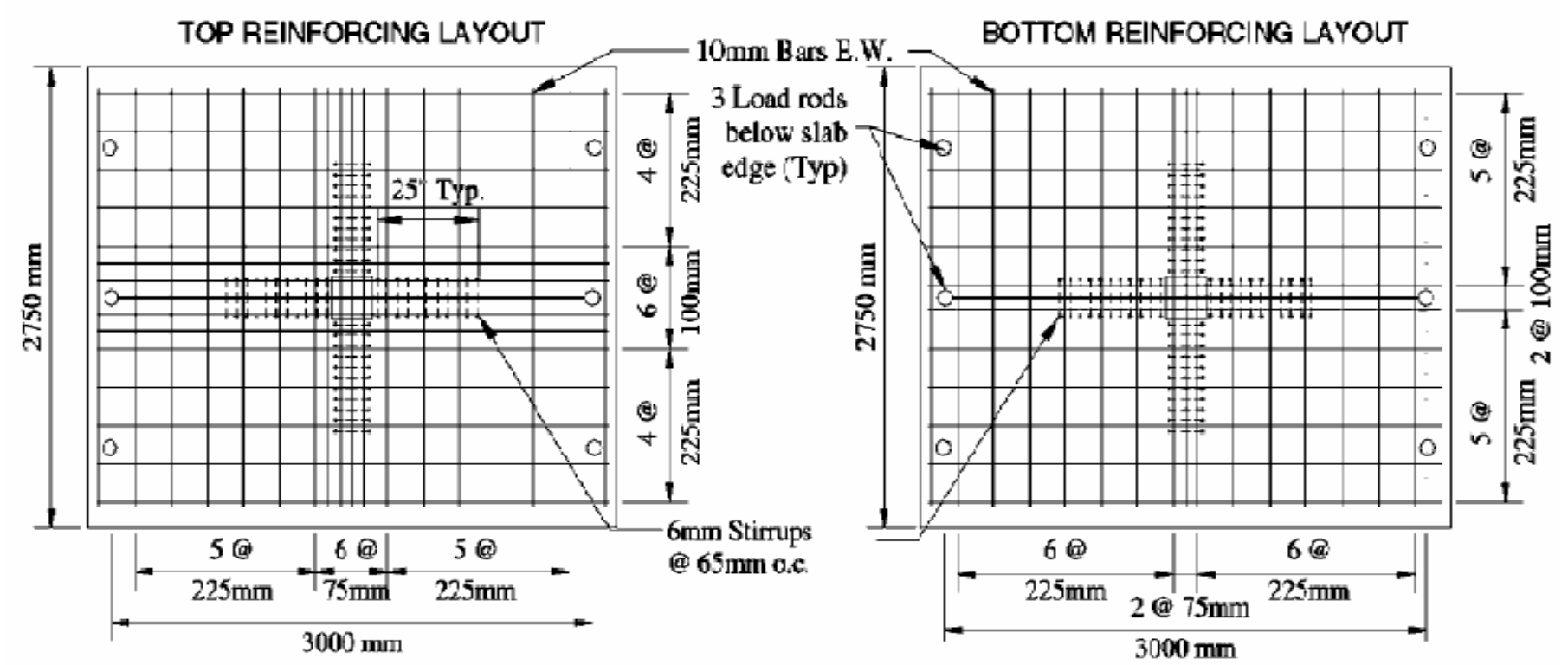

Fig.4 Slab flexural and shear reinforcement layout 


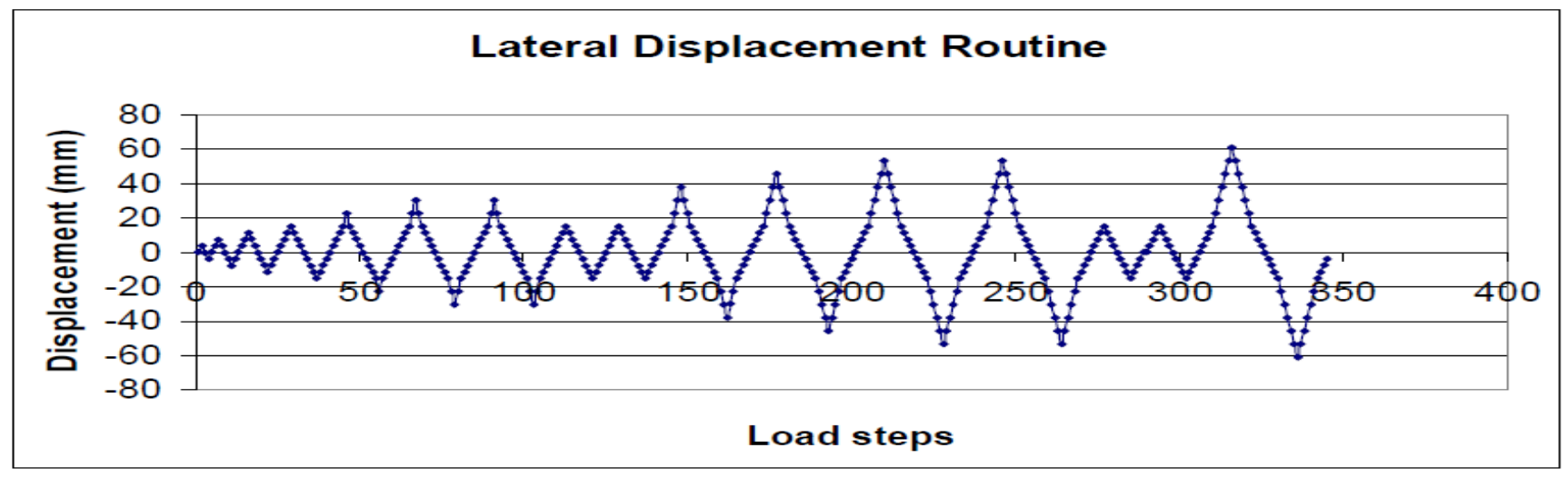

Fig 5 Lateral displacement routine adopted in the experiment

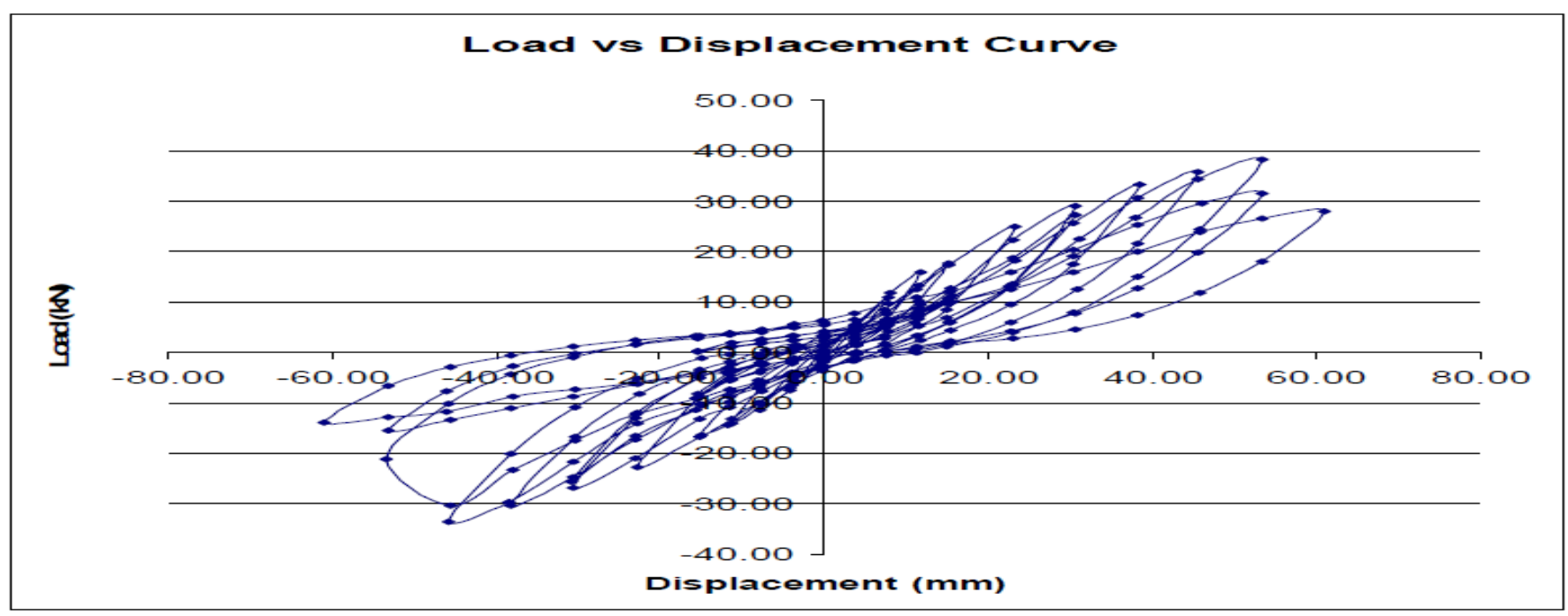

Fig 6 Load deflection hysteretic curve
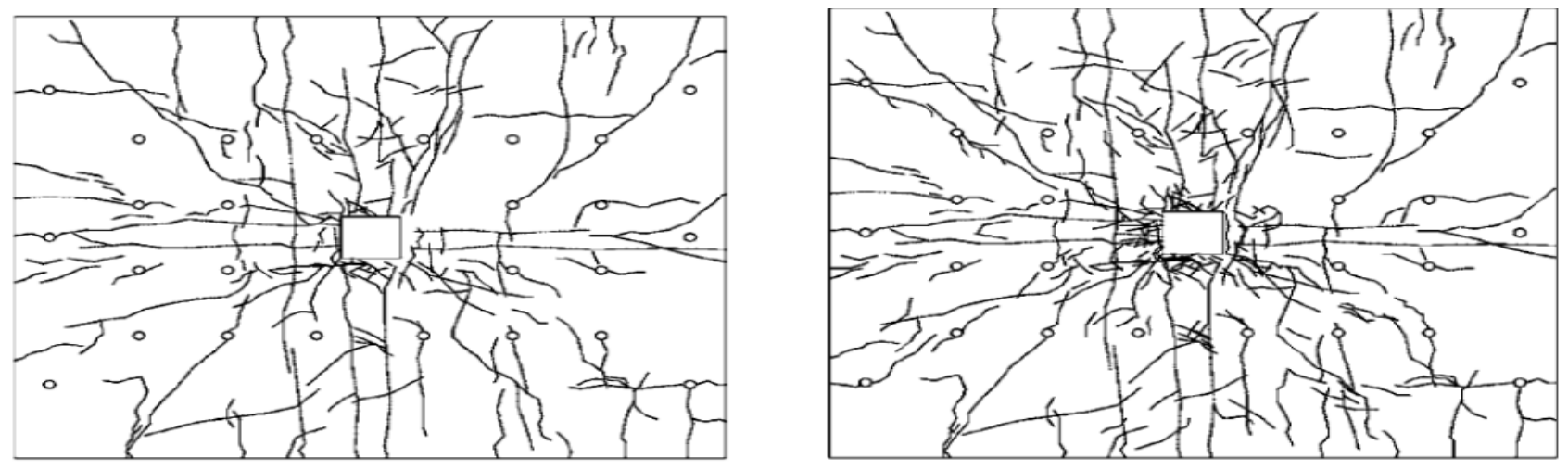

Fig. 7 Crack Pattern and punching failure of Slab

\section{FINITE ELEMENT MODEL:}

Finite element modeling package, FEMAP is used to model the Flat plate column joint. Following are the steps involved in the modeling of joint.

$>$ Solid elements are used to model concrete and bar elements are used to model reinforcement.
Slab is allowed to translate in loading direction alone at load rod positions and constrained in other ( $\mathrm{Y} \& \mathrm{Z}$ ) directions. Gravity load is applied on the slab in the form of point loads.

$>$ Bottom of the column is hinge supported and the predetermined cyclic lateral displacement routine is applied at the top of the column. 
$>$ The Bond to the reinforcement is modeled by inputting Bond-Slip curve in the analysis.

$>\quad$ The finite element model developed in FEMAP is transferred to MASA for the analysis.

$>\quad$ The finite element mesh for the Flat plate column joint model is shown in figures 8 and 9 .The reinforcement layout for model without slab shear reinforcement is shown in figure 10 .

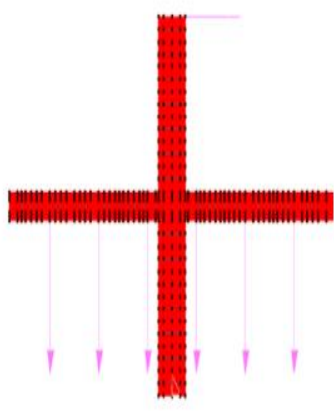

Side View

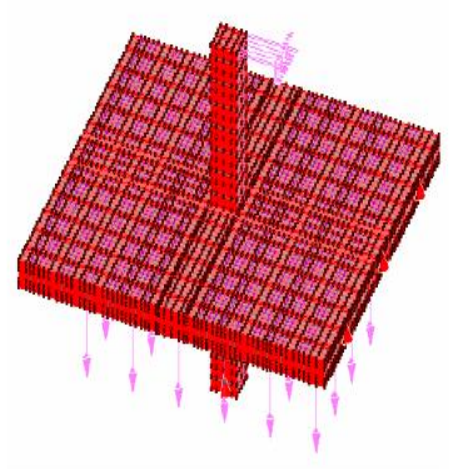

Isometric View
Fig 8 Geometry of the Model

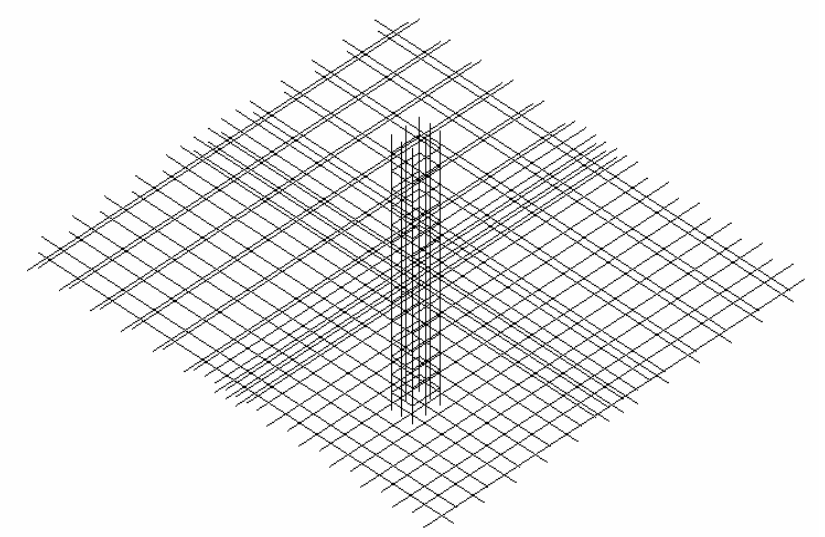

Fig 9 Configuration of reinforcement bar elements for model without slab shear reinforcement

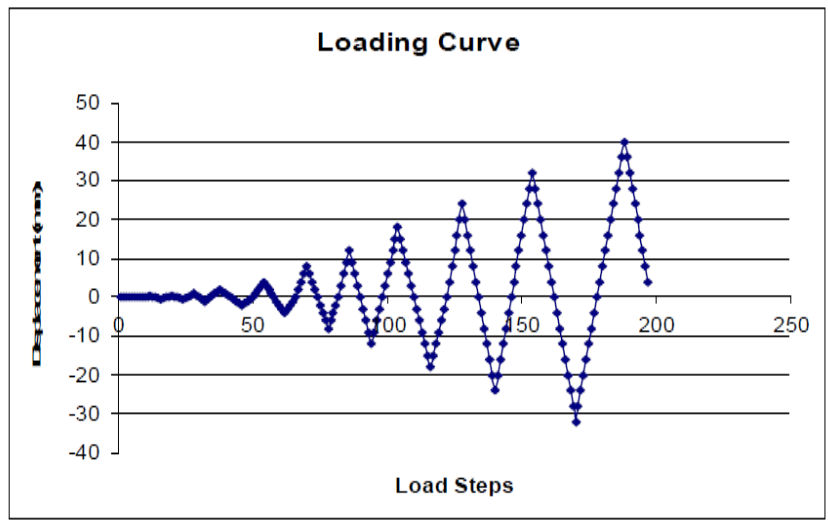

Fig 10 Lateral displacement routine adopted in the modeling

\subsection{Finite Element Model Results}

The Finite element model supported a peak lateral load of $35.59 \mathrm{kN}$ at drift of $1.2 \%$. The figure 11 shows hysteretic curve for Finite element model.

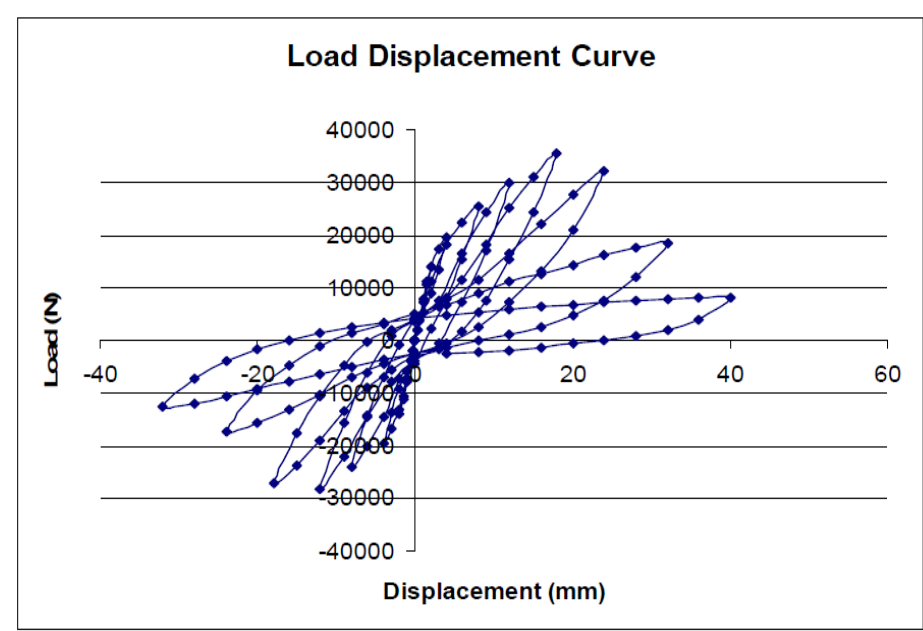

Fig 11 Load deflection hysteretic curve for finite element model

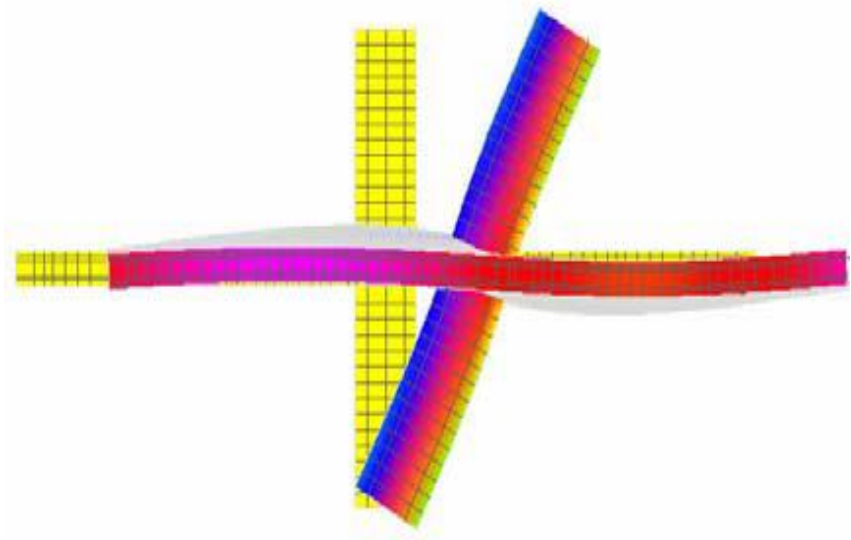

Side view

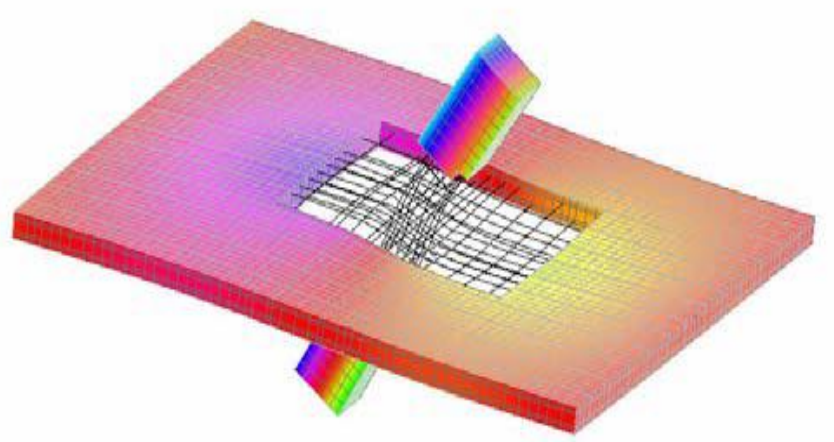

Isometric view 


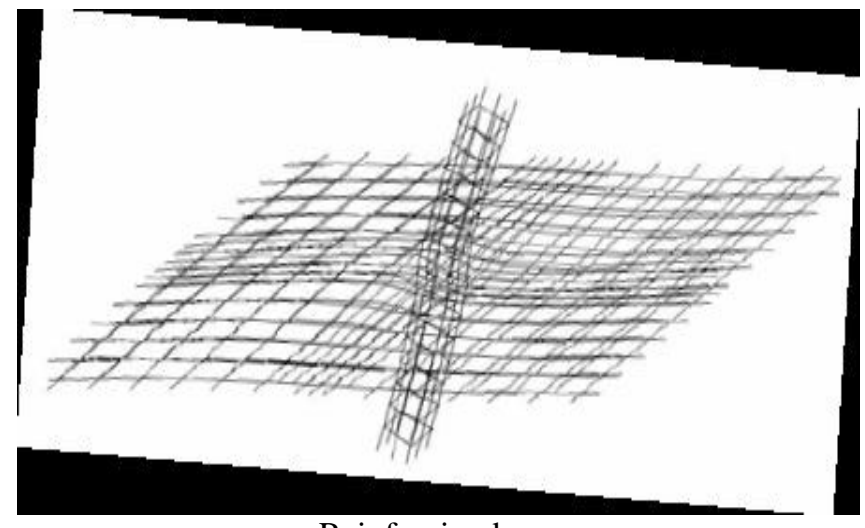

Reinforcing bars

Fig 12 Deformed Shape of the model in different views

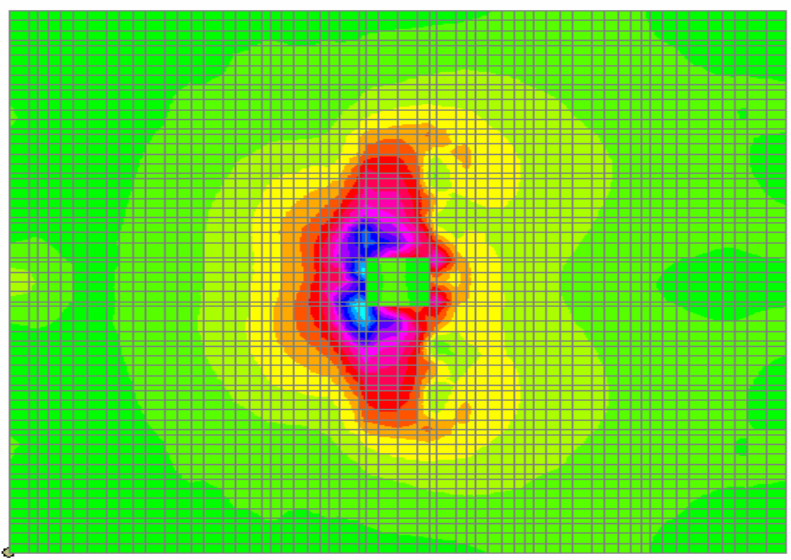

Fig 13 Stress distribution in the elements

Table 2 Analysis results from MASA

\begin{tabular}{|c|c|c|c|c|}
\hline $\begin{array}{c}\text { Compressive } \\
\text { strength of } \\
\text { concrete } \\
\mathrm{fc}^{\prime}\end{array}$ & $\begin{array}{c}\text { Peak } \\
\text { lateral } \\
\text { load }\end{array}$ & $\begin{array}{c}\text { Drift at } \\
\text { peak } \\
\text { load }\end{array}$ & $\begin{array}{c}\text { Unbalanced } \\
\text { moment } \\
\mathrm{Mu}\end{array}$ & $\begin{array}{c}\text { Shear } \\
\text { force } \\
\mathrm{Vu}\end{array}$ \\
\hline$(\mathrm{MPa})$ & $(\mathrm{kN})$ & $(\mathrm{mm})$ & $(\mathrm{kN}-\mathrm{m})$ & $(\mathrm{kN})$ \\
\hline 35.35 & 35.59 & 18.00 & 54.27 & 36.50 \\
\hline 35.35 & -28.13 & -12.00 & -42.90 & 34.90 \\
\hline
\end{tabular}

\section{COMPARISON OF EXPERIMENTAL AND}

\section{NUMERICAL RESULTS:}

The comparison of load-deformation behavior of flat plateColumn joint from experimental and numerical results is shown in table 3 .

Table 3 Comparison of experimental and numerical results

\begin{tabular}{|l|l|l|l|}
\hline $\begin{array}{l}\text { Results } \\
\text { from }\end{array}$ & Direction & $\begin{array}{l}\text { peak lateral } \\
\text { load(kn) }\end{array}$ & $\begin{array}{l}\text { Drift at peak } \\
\text { load(mm) }\end{array}$ \\
\hline \multirow{2}{*}{ Experiment } & Positive & 38.30 & 53.31 \\
\cline { 2 - 4 } & Negative & -33.60 & -45.66 \\
\hline \multirow{2}{*}{ MASA } & Positive & 35.59 & 18.00 \\
\cline { 2 - 4 } & Negative & -28.13 & -12.00 \\
\hline
\end{tabular}

Above observations (table 3) indicate that the FE model over-estimates the actual stiffness of the connection Following parameters are examined in this paper.

$>$ Load deformation behavior.

$>$ Drift capacity-Interstory drift ratio is the difference of lateral deflection between two successive floors divided by the floor height. Drift ratios for flat plate-column joint with out slab shear reinforcement are compared and tabulated in the table 4 .

Table 4 Comparison of drift ratios

\begin{tabular}{|l|l|l|l|}
\hline $\begin{array}{l}\text { Type of Shear } \\
\text { Reinforcement }\end{array}$ & Cycle & $\begin{array}{l}\text { Drift at } \\
\text { Peak }(\%)\end{array}$ & $\begin{array}{l}\text { Drift at } \\
\text { Ultimate(\%) }\end{array}$ \\
\hline \multirow{2}{*}{ NS } & Positive & 1.82 & 3.64 \\
\cline { 2 - 4 } & Negative & -1.21 & -3.64 \\
\hline
\end{tabular}

> Ductility-The model with no slab shear reinforcement which failed due to punching shear around the slab-column connection has the least value of ductility.

Table 5 Comparison of Ductility values

\begin{tabular}{|l|l|l|l|}
\hline $\begin{array}{l}\text { Type of Shear } \\
\text { Reinforcement }\end{array}$ & \multicolumn{4}{|l|}{ Ductility } \\
\hline & Positive & Negative & Cumulative \\
\hline NS & 2.67 & 3.00 & 5.67 \\
\hline
\end{tabular}

\section{CONCLUSION}

Flat plate-column connections without slab shear reinforcement are modeled and analyzed under combined gravity and cyclic lateral loading. Based on comparison of the results of these models, the following conclusions are drawn:

$>$ Punching shear failure can arise in case of flat plate-column joint without slab shear reinforcement. It is brittle failure which reduces lateral load carrying capacity of connection suddenly.

> May be Use of Slab shear reinforcement improves the overall behavior of the connection in terms of ductility, energy dissipation capacity, resisting punching failure and drift capacity.

$>\quad$ The ductility of the joint under monotonic loads is significantly higher than that under cyclic loading. Under Monotonic loading use of slab shear reinforcement does not affect much the behavior of connection.

$>$ Grade of steel of slab shear reinforcement does not affect much the behavior of the connection.

$>$ The study needs to be extended to exterior slabcolumn connections.

$>$ Refinement of deformation is necessary in the modeling of joint.

$>\quad$ An analytical model using strut and tie model needs to be developed for slab column connections for its analysis and design. 


\section{ACKNOWLEDGEMENTS}

I am thankfully to professor \& Head, department of civil engineering, Principal of ACS college of engineering and my friends ,Bangalore, Karnataka India.

\section{REFERENCES}

[1]. ACI Committee 318 (2005), "Building Code Requirement for Reinforced Concrete and

Commentary," American Concrete Institute, Farmington Hills, USA.

[2]. Amin Ghali., and Ramez B. Gayed. (2006), "SeismicResistant Joints of Interior

Columns with Prestressed Slabs," ACI Structural Journal, Vol. 103, No.5, September-

October 2006, pp. 710-719.

[3]. Austin D. Pan., and Jack P. Moehle. (1992), “An Experimental Study of Slab-Column

Connections," ACI Structural Journal, Vol. 89, No.6, November-December 1992, pp.626-638.

[4]. Ian N. Robertson., Tadashi Kawai., James Lee., and Brian Enomoto. (2002), "Cyclic Testing of Slab-Column Connections with Shear Reinforcement," ACI Structural Journal,Vol. 99, No.5, September-October 2002, pp. 605613. 